\title{
ТЕОРЕТИЧЕСКИЕ ПОДХОДЫ К ПРЕВЕНЦИИ АСОЦИАЛЬНОГО ПОВЕДЕНИЯ УЧАЩИХСЯ
}

\begin{abstract}
Аннотация. В статье, определены теоретические подходы превенщии асоциального поведения учащихся: превентивный, системный, деятельностный и иелостный. Опосредованные основополагающей идеей антиципаиии, каждый подход раскрывает кониептуальную линию превентивной деятельности. Кроме основополагающих подходов разрабатываемая модель, предполагает наличие цели и задач способствующие максимальной реализации важнейших теоретических основ парадигмы превентивной деятельности. Представлены основные виды и бормы психологической работы относительно рассматриваемых подходов.
\end{abstract}

Ключевые слова: превенция, антиципация, превентивный, системный, деятельностный, иелостный, подход

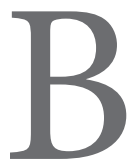

настоящее время, проблема психологической превенции асоциального поведения в аспекте теоретического изучения и логического обоснования ее построения в психологической науке признается одной из наиболее актуальных проблем. Анализ психолого-педагогической литературы отечественных и зарубежных авторов позволил нам определить понятие превенции. Под превенцией асоциального поведения мы понимаем комплекс мер психологического воздействия на личность учащегося всеми членами образовательной среды, включенными в коррекционную деятельность, основанную на глубоком понимании того, что такая деятельность должна строиться на антиципации, позволяющего предвосхищать, предупреждать и прогнозировать пути вывода учащегося из ситуации асоциального поведения.

Тогда как под профилактикой асоциального поведения мы понимаем воздействие на образовательную среду с целью создания психологических условий снижающих вероятность возникновения тех или иных трудностей в поведении учащихся, опосредованное повышением психологической культуры всех субъектов образовательной среды.

Основываясь на определение эмпирических референтов превентивной и профилактической работы, разрабатываемая нами концептуальная модель превенции асоциального поведения базируется на основополагающей идее антицииаиии, как психического свойства субъектов участников образовательной деятельности, «способности действовать и принимать решения с определенным временно-пространствен- ным упреждением в отношении ожидаемых, будущих событий» ${ }^{1}$.

Как и любая способная к функционированию и развитию модель, предполагает наличие цели, задач и основополагающих подходов, способствующие максимальной реализации важнейших теоретических основ парадигмы превентивной деятельности.

Целью предложенной нами модели является превенция асоциального поведения учащихся в образовательных учреждениях.

Исходя из целеполагания, нами были выделены следующие задачи превенции асоциального поведения учащихся:

1. Формирование у учителей антиципационных способностей, как конкретного «состояния» системы внутренних ресурсов индивида, обеспечивающих успешность прогностической деятельности в превенции асоциального поведения учащихся.

2. Формирование у педагогов психологической культуры взаимоотношения и взаимодействия с учащимися (через коррекцию взаимоотношения в системе «учитель-ребенок»).

3. Формирование умения принятия учителем решения оптимальных мер педагогического воздействия, с учетом индивидуально-типологических и социальнопсихологических особенностей учащихся.

4. Обеспечение совместной работы психолога, родителей и педагогов по выработке индивидуального подхода к каждому ученику.

\footnotetext{
1 Ломов Б.Ф., Сурков Е.Я. Антиципация в структуре деятельности. М.: Наука, 1980.
} 


\section{Психология развития}

5. Формирование у родителей психологической культуры взаимоотношений в системе «родительребенок».

6. Обеспечение оптимизации перехода учащихся из начальной школы в среднее звено (через создание педагогических команд).

7. Определение условий, способствующих личностному и профессиональному самоопределению учащихся, а также самовоспитанию.

8. Определение условий, способствующих снижению эмоционального выгорания учителей и психологической их деформации.

При создании процессуальной модели превенции асоциального поведения учащихся мы основывались на положения превентивного, системного, деятельностного и целостного подходов.

Сущностным компонентом содержания превентивного подхода является формирование антиципации. В настоящее время идеи антиципации (прогнозирования) активно проникают в психолого-педагогическую науку и практику, формируя новые представления о возможностях развития антиципационных способностей у учителей в зависимости от характера решаемых задач.

Выделение в качестве теоретической и практической основы решения проблемы превентивного подхода обусловлено отсутствием или недостаточно сформированных антицииационных способностей у субъектов образовательной деятельности, способности прогнозирования в соответствии с учетом индивидуальных и личностных особенностей учащихся.

Основной функцией прогнозирования является опережающее отражение педагогической действительности и, соответственно, получение опережающей информации о возможных последствиях педагогических воздействий. Педагогическое прогнозирование (прогнозирование вообще), как отмечалось выше, предшествует принятию учителем решения о мерах педагогического воздействия, дает учителю возможность выбрать наиболее оптимальные, с точки зрения целей учебно-воспитательного процесса, варианты принятия решения ${ }^{2}$.

Превентивный подход, в нашей модели, прежде всего, связан с организацией выбора средств для осуществления прогностической деятельности, который позволяет раскрыть процессуальные особенности превенции асоциального поведения учащихся.

Значимость превентивного подхода для моделирования процесса собственно превенции асоциального поведения учащихся состоит в том, что позволяет решать следующие задачи:

2 Абасов 3.А. Формирование прогностических способностей у учителей // Образование в современной школе. 2004. № 6.
- формирование антиципационных способностей у взрослых субъектов образовательной деятельности в решении конкретной прогностической задачи;

- осуществление подбора средств и методов в соответствии с возможностью получения опережающей информации о будущем состоянии, перспективах и тенденциях развития тех или иных объектов и явлений на основе анализа данных об их прошлом и нынешнем состоянии;

- осуществление подбора психологических методик способствующих не только констатировать те или иные психологические факты, но и позволяющие раскрыть следствия;

- развитие рефлексивной сферы взрослых субъектов образовательной деятельности, что позволяет наиболее эффективному взаимодействию с учащимися.

Превентивный подход в нашей модели осуществляется через призму конкретных форм психологических видов работ, в которых отражается суть прогнозирования поведения учащегося взрослыми субъектами.

Превенция асоциального поведения учащихся осуществляется психологом-педагогом, которая включает в себя работу с администрацией школы, с учителями, социальным педагогом, родителями и непосредственно с учащимися. Она осуществляется в различных формах работ со всеми перечисленными субъектами образовательного процесса.

В основу содержания превенции асоциального поведения учащихся в спектре рассматриваемого подхода входят следующие виды психологической работы:

С учителями:

1. Проведение тематических семинаров, для обеспечения педагогов знаниями о современных концепциях развития и воспитания ребенка, о стилях семейного воспитания, о сложившихся социальнопсихологических типах личности.

2. Проведение тематических семинаров, для формирования навыков использования диагностической информации о характерологических свойствах личности и обеспечения коррекции их отношения к «проблемным учащимся».

3. Проведение индивидуальных консультаций по вопросам межличностных взаимоотношений с «проблемным учащимся».

4. Определение стратегий педагогической помощи учащимся, испытывающим определенные трудности в обучении, поведении и психологическом самочувствии.

5. Определение педагогической стратегии и тактики собственной деятельности в рамках обучения и социализации учащихся. 


\section{Психология и психотехника 8(59) • 2013}

\section{С родителями:}

1. Проведение родительских собраний для обеспечения родителей знаниями о современных концепциях развития и воспитания ребенка, о стилях семейного воспитания, о сложившихся характерологических свойствах у детей.

2. Проведение психодиагностики по определению социально-психологического типа личности учащегося на родительских собраниях.

3. Проведение индивидуальных консультаций по проблемам личностного развития учащегося по результатам психодиагностического исследования социально-психологического типа личности.

4. Проведение тематических семинаров по проблемам родительских отношений.

Содержание превентивной деятельности строится на основе общей организационной программы, включающей в себя частные программы для работы психолога с:

- родителями;

- учителями;

- администрацией;

- учащимися.

В превентивной модели мы опираемся и на системный подход. Системный подход это ориентация в педагогической деятельности на основе учета знаний личности как системной структуры, включающей в себя такие составляющие как темперамент, характер, способности, на основе которых педагог может эффективно выстроить процесс воспитания, а при необходимости и перевоспитания учащегося.

В основу системного подхода легли теоретические положения В.М. Миниярова ${ }^{3}$, в которых личность рассматривается как структура, в элементах которой прослеживается диалектическая взаимосвязь. В предлагаемом автором структурно-системном подходе к характеристике личности видно как каждый элемент подструктуры отражает ряд свойств личности, которые становятся ступенькой в объяснении функционирования каждого следующего элемента и целом всей личности.

Для педагогов важно знать как системную структуру, так и функциональную подструктуру личности. Знание системной структуры личности необходимо для того, чтобы четко себе представлять объект воспитания, так как, зная темперамент, характер, способности, физические качества учащегося, можно выработать индивидуальную, групповую и коллективную программы педагогических воздействий с целью нормального формирования лич-

3 Минияров В.М. Психология семейного воспитания (диагностико-коррекционный аспект). М.: Московский психолого-социальный институт; Воронеж: НПО «МОДЭК», 2000. ности. Зная функциональную подструктуру личности ученика, педагог может контролировать и оперативно управлять ходом процесса воспитания, так как по потребностям учащихся можно судить об иерархии ценностных ориентаций, по мотивационному компоненту судить о социальной направленности учащихся.

Важнейшим элементом изучения личности является характер, предопределяющий становление положительных или отрицательных установок личности. Знание характера школьника даст возможность учителю организовать процесс воспитания, а при необходимости и перевоспитания отдельных учащихся. Информация в целом даст возможность учителю планировать учебно-воспитательный процесс не от желаемых нормативных требований, а прежде всего от реального состояния и возможностей учащихся, т.е. от того достигнутого уровня, на котором находится ученик.

В получении информации о психологических характеристиках субъектов образовательной деятельности системный подход представлен и в контексте его системного исследования.

Главная функция системного описания состоит в интеграции информации об объекте. Задачей системных исследований является, прежде всего, выработка соответствующей теоретико-познавательной технологии изучения явлений как систем и познания системности самого мира. Использование данного подхода позволяет рассмотреть типологии как целостные структурные образования, состоящие из элементов (типов), функционально связанных между собой, названные К.Б. Малышевым «типологическими системами» ${ }^{4}$.

Для эффективного применения системного подхода в превентивной модели, необходимо создание следующих условий:

1. Использование целостной системно-базисной типологической структуры к получению психологической информации о характеристиках субъектов образовательной деятельности.

2. Диагностика должна быть построена с учетом принципа типологизации психологической информации об объекте. Знание данных характеристик дает возможность психологу эффективно работать с малыми однородными группами, уточнять и систематизировать эти характеристики.

3. Диагностика должна носить комплексный характер, на основе учета главных личностных качеств характера, способности, направленности личности, ее жизненных планов и ориентаций, образа мышления, мотивов и другие.

\footnotetext{
4 Малышев К.Б. Многомерный типологический подход к получению информации о субъектах образовательной деятельности: автореф. дисс. ... д-ра психол. наук. Самара, 2006.
} 


\section{Психология развития}

Задача диагностики личности как учебного предмета: обеспечить профессиональную деятельность учителя диагностической технологией, с помощью которой он получает возможность:

1) вырабатывать педагогически оправданные решения в системе отношений «учитель-ученик»;

2) оценивать результативность предшествующей педагогической деятельности на начало нового педагогического воздействия;

3) определять социально-педагогический тип личности школьника и учителя в процессе их взаимодействия;

4) устанавливать перспективы дальнейшего формирования диагностируемой личности;

5) организовать совместную деятельность учителя, родителей, педагогического коллектива ${ }^{5}$.

4. Изучение личностных особенностей учащихся должны входить в содержание таких форм работы, как лекции, семинары, консультации, тренинги. Важным требованием к данным формам работы чтобы они имели не абстрактно-теоретический уровень, а основанием являлось изучение конкретных учащихся, с учетом всей информации, накопленной о личности, которое способствует разработке и планированию стратегии превенции каждого учащегося.

5. В вышеперечисленных формах работ эффективно использование таких методов, как кейс-стади, упражнения, дискуссии по проблеме и другие, предполагающие решение конкретных задач, требующих наиболее полной информации о личностных особенностях ребенка.

Для конструирования стратегии взаимодействия администрации с субъектами образовательной деятельности с целью организации превенции асоциального поведения учащихся нами был использован деятельностный подход.

Основная идея деятельностного подхода в превенции связана не с самой деятельностью как таковой, а с деятельностью как средством становления и развития субъектности ребенка. Деятельностный подход понимается как организация активной социально-направленной деятельности, создание необходимых условий для становления и развития субъектности учащегося: творчества, непрерывного поиска новых задач, средств, действий, волевых актов субъектов деятельности, общения, активной жизненной позиции, а также для выработки алгоритма социально приемлемого поведения учащихся.

5 Минияров В.М. Психология семейного воспитания (диагностико-коррекционный аспект). М.: Московский психолого-социальный институт; Воронеж: НПО «МОДЭК», 2000.
Как отмечают Е.Н. Степанов и Л.М. Лузина, ситуация воспитывающей деятельности должна содержать в себе: социальные факторы, инициирующие возникновение многообразных духовных потребностей и формирования мотивов общественной и личностно значимой созидательной деятельности, требующей непрерывной рефлексии (оценки, осмысления); возможность и необходимость осуществления многообразных видов подобной деятельности, требующих творчества, непрерывного поиска новых задач, средств, действий, волевых актов субъектов деятельности, общения, активной жизненной позиции, принципиальности, последовательности в отстаивании своих взглядов, бескорыстного риска, сверхнормативной активности, готовности не только следовать к намеченной цели, но и конструировать новые, более интересные и продуктивные цели и смыслы уже в процессе деятельности ${ }^{6}$.

При планировании и организации деятельности в процессе превенции асоциального поведения следует выбирать наиболее адекватную целям и задачам модель деятельности, чтобы в ее содержании, формах и методах реализации были учтены индивидуальные особенности, выражающиеся в его способностях, интересах, характере ребенка. Должна учитываться и посильность сложности ситуации, которые ребенок был бы в состоянии разрешить, а разрешение их направляло бы его в положительное русло развития.

Таким образом, опора модели на деятельностный подход сводится к необходимости изучения учащегося в совокупности его включенности в деятельность. Непосредственная включенность межсубъектных отношений учителя и учащихся в такие виды деятельности как общение, учебно-познавательный процесс, внеурочная деятельность способствовала включению в превентивную модель таких методов как наблюдение, кейс-стади, дискуссия.

В превентивной деятельности нами используется целостный подход, под которым понимается совокупность деятельности различных социальных институтов и звеньев, объединенных общими педагогическими задачами в организации воспитания и самовоспитания учащихся общеобразовательных учреждений.

Модель превенции асоциального поведения имеет свою структуру, упорядоченное множество своих взаимосвязанных элементов, объединенных общей целью функционирования и единства управления. В то же время она не может существовать вне педагогического процесса, который так же рассматривается как система, т.е. совокупность элементов, находящихся в определен-

6 Степанов Е.Н., Лузина Л.М. Педагогу о современных подходах и концепциях воспитания. М., 2002. Гл. II. 


\section{Психология и психотехника 8(59) • 2013}

ных отношениях и связях между собой и образующих соответствующую целостность, единство.

Современные технологии воспитания осуществляют комплексный подход, выполняя обязательные требования:

1. Воздействуют на воспитанников по трем направлениям - на сознание, чувства и поведение.

2. Положительный результат достигается при органичном слиянии воспитания (внешнего педагогического воздействия) и самовоспитания личности.

3. Единство и координация усилий всех имеющих отношение к воспитанию социальных институтов и объединений, прежде всего средств массовой информации, литературы, искусства, семьи, школы, органов правопорядка, коллективов и групп - непременное условие целостного подхода.

4. Заданные качества личности формируются через систему конкретных воспитательных дел. Эти дела должны иметь подчеркнуто комплексный характер, требующий одновременного осуществления задач умственного, физического, нравственного, эстетического и трудового воспитания в органически слитом процессе.
5. Управление процессом воспитания может быть успешным тогда, когда будут учтены действующие в воспитании внешние и внутренние факторы и взаимосвязи между ними.

При целостном подходе к формированию целостной личности должна быть учтена совокупность всех этих условий. Благоприятные для личности и общества изменения в результате воспитания достигаются не только благодаря прямому воздействию на ту или иную сферу психики формирующейся личности, но и при изменении внешних условий, которые препятствуют развитию нежелательных отклонений от нормы и сводят к минимуму отрицательные явления. Целостность в таком контексте означает непротиворечие замысла и путей его осуществления, соответствие результатов поставленным целям и задачам.

Таким образом, теоретические подходы, основанные на основополагающих идеях отечественных авторов, раскрывают концептуальную линию превентивной деятельности, что способствует максимальной реализации важнейших теоретико-методологических основ ее парадигмы.

\section{Список литературь:}

1. Абасов 3.А. Формирование прогностических способностей у учителей // Образование в современной школе. 2004. № 6. С. 50-55.

2. Бочарова Е.Е. Теоретико-концептуальные основания исследования проблемы субъективного благополучия // Вестник Московского государственного областного университета. Серия: Психологические науки. 2012. № 2. С. 38-44.

3. Ломов Б.Ф., Сурков Е.Я. Антиципация в структуре деятельности. М.: Наука, 1980. 279 с.

4. Малышев К.Б. Многомерный типологический подход к получению информации о субъектах образовательной деятельности. Автореф. дисс. ... докт. психол. наук. Самара, 2006. 41 с.

5. Минияров В.М. Психология семейного воспитания (диагностико-коррекционный аспект). М.: Московский психолого-социальный институт; Воронеж: НПО «МОДЭК», 2000. 256 с.

6. Степанов Е.Н., Лузина Л.М. Педагогу о современных подходах и концепциях воспитания. М., 2002.147 с.

\section{References (transliteration):}

1. Abasov Z.A. Formirovanie prognosticheskih sposobnostey u uchiteley // Obrazovanie v sovremennoy shkole. 2004. № 6. S. 50-55.

2. Bocharova E.E. Teoretiko-konceptual'nye osnovaniya issledovaniya problemy sub'ektivnogo blagopoluchiya // Vestnik Moskovskogo gosudarstvennogo oblastnogo universiteta. Seriya: Psihologicheskie nauki. 2012. № 2. S. 38-44.

3. Lomov B.F., Surkov E.Ya. Anticipaciya v strukture deyatel'nosti. M.: Nauka, 1980. 279 s.

4. Malyshev K.B. Mnogomernyy tipologicheskiy podhod k polucheniyu informacii o sub'ektah obrazovatel'noy deyatel'nosti. Avtoref. diss. ... dokt. psihol. nauk. Samara., 2006. $41 \mathrm{~s}$.

5. Miniyarov V.M. Psihologiya semeynogo vospitaniya (diagnostiko-korrekcionnyy aspekt). M.: Moskovskiy psihologosocial'nyy institut; Voronezh: NPO «MODEK», 2000. 256 s.

6. Stepanov E.N., Luzina L.M. Pedagogu o sovremennyh podhodah i koncepciyah vospitaniya. M., 2002. 147 s. 